\title{
Recommendations for Traceability and Use of USDA Premise IDs for Swine Exhibition at Terminal Shows in Florida ${ }^{1}$
}

\author{
Heidi Hill, Morgan McKinney, T. Langford, Clayton Roland, Charles Carr, and Pamela Hunter²
}

\section{Introduction}

Animal disease traceability has become an increasingly important topic within animal agriculture. Disease traceability plays an important role in identifying where diseased and at-risk animals are located. An accurate traceability system does not prevent disease; however, it shortens the response time for identifying and reducing the effects of disease outbreaks (USDA-APHIS, 2018).

\section{Premise Identification Tags}

The Premise Identification Number (PIN) tag provides an option for identification of hogs to the premise they were kept immediately before entering harvest channels. The PIN tag or Premise ID tag will be collected as the official form of identification associated with any blood or tissue samples collected for disease surveillance (USDA-APHIS, 2009).

\section{How to Obtain a Premise ID}

Premise ID can be obtained by registering with the Florida Department of Agriculture and Consumer Services. The application for Premise Identification can be found at http://forms.freshfromflorida.com/09215.pdf.

\section{Intrastate Transport}

Swine transported within the state of Florida should abide by Florida statute for intrastate movement which states that "Florida-origin swine for exhibition must be accompanied by an Official Certificate of Veterinary Inspection, also known as a health certificate, dated not more than 90 days before exhibition." Health certificates can be obtained from a state licensed veterinarian. However, most Florida terminal livestock shows will have a veterinarian issue a health certificate associated with all of the market animals at a given exhibition.

\section{Recommendations for County and State Livestock Shows and Breeders}

\section{County and State Livestock Shows}

- If pigs do not already have a premise ID tag, personnel from that terminal show should apply a plastic premise ID tag associated with that particular fair. If pigs already have a premise tag, personnel from that show should record the existing tag and add an additional premise ID associated with that show.

1. This document is 4HSWFS20, one of a series of the 4-H Youth Development Program, UF/IFAS Extension. Original publication date October 2018. Visit the EDIS website at https://edis.ifas.ufl.edu for the currently supported version of this publication.

2. Heidi Hill, graduate student; Morgan McKinney, graduate student; T. Langford, graduate student; Clayton Roland, graduate student; Charles Carr, associate professor, Department of Animal Sciences; and Pamela Hunter, veterinarian manager, Department of Agriculture and Consumer Services, Division of Animal Industry; UF/IFAS Extension, Gainesville, FL 32611. 
- Terminal shows may also provide an informational sheet to the exhibitor on the purpose of Premise ID tags and the prevention of the spread of diseases (examples: prevent comingling without proper quarantine; prevent contact with feral pigs).

- In the event pig does not meet exhibition requirements, a release of liability form or documentation should be signed by a veterinarian and a parent or guardian of the exhibitor describing the health disposition of the pig upon release back to the exhibitor.

\section{Breeders}

- Florida's breeders are encouraged to apply premise ID before marketing pigs to youth who will exhibit in terminal shows to assist with traceability.

\section{Future Recommendations}

In the future, exhibitors are encouraged to obtain their own Premise ID's for each location where pigs are being housed.

\section{Additional Information}

Application for Official Identification Devices: https://

forms.freshfromflorida.com/09246.pdf

Florida Department of Agriculture and Consumer Services (FDACS): https://www.freshfromflorida.com/ Business-Services/Animals/Animal-Movement/

Swine-Movement-Requirements

Florida Department of Agriculture and Consumer Services (FDACS) - Application for Premises Registration: http:// forms.freshfromflorida.com/09215.pdf

Obtaining Official USDA Swine Premises Tags: http:// www.allflexusa.com/our-products/swine/product/ official-usda-swine-premises-tags

\section{Resources}

USDA-APHIS. 2009. "Official Premises Identification Number (PIN) Tags for Slaughter Swine." https://www.aphis. usda.gov/traceability/downloads/Swine_Premises_ID_Tags. pdf

USDA-APHIS. 2018. "Animal Disease Traceability." https://www.aphis.usda.gov/aphis/ourfocus/animalhealth/ traceability 